\title{
Guest editorial Value Chains - Linking Theory and Practice
}

\author{
Martin Franz and Florian Warburg
}

Today more and more information about products in the supermarket shelves are brought to consumers from various sources. Marketing agencies use a food's biography to distinguish it from other products. State institutions regulate the labelling obligations for products. Non-governmental organizations (NGOS) or journalists publish scandalous production circumstances. Researchers try to analyse the flows of produce in case studies for processes of globalization. In addition, everybody who tries to provide the consumer with more information has his or her own agenda from economic, political or ideological aims. Each involved party provides consumers with a varying product biography (or a fragment of it) and in the end, every consumer paints his or her own picture based on one's subjective opinion of the product and its origin. Cook (2006) names a multitude of researchers and studies from various disciplines that follow the flow of food from farmers to consumers. All of the research ends with the question "But what's the theoretical and political point in [...] doing that? And how can it be done?".

There is no simple or solitary answer to this question. Since Hopkins and Wallerstein have published their original Commodity Chain approach in 1977, a growing number of theories and studies has been developed that deal with the analysis of the relationships between the production, the trade and the consumption of goods (Neilson \& Pritchard, 2009). Today value chain is an umbrella term, which includes diverse approaches like Commodity Chains (Hopkins \& Wallerstein, 1977), Value Chains or Value-adding Chains (e.g. Porter, 1985), Commodity Systems (e.g. Friedland, 2005), Systems of Provision (e.g. Fine \& Leopold, 1993), Filière (e.g. Lenz, 1997), Commodity Circuits (e.g. Cook \& Crang, 1996), Global Commodity Chains (e.g. Gereffi \& Korzeniewicz, 1994), Global Value Chains (e.g. Gereffi et al., 2005) and Global Production Networks (e.g. Henderson et al., 2002). This “[...] plethora of different approaches in the field has arguably complicated, rather than simplified, the task of drawing together key conclusions" (Neilson \& Pritchard, 2009: 31). 
The development of most of these approaches is strongly linked to the analysis of the production, the trade and the consumption of agricultural products. Many case studies have focused on agricultural products (e.g. Neilson \& Pritchard, 2009 about tea and coffee, Franz \& Hassler, 2010 about pepper, Dannenberg, 2011 about fruits and vegetables, Challies \& Murray, 2011 about berries). But that is not all. Such approaches are also used to analyse many other products or services. The decision for one or another analytical framework depends on the background of the authors and their aims. While economists often tend to use primary approaches, like the ValueAdding Chain approach by Porter (e.g. 1985), economic geographers and sociologists more often use the Global Value Chains (GVC) or Global Production Networks (GPN) approaches. The latter two approaches are no simple frameworks for the analysis of value adding activities. They (with different emphasis) analyse the interrelations between governance structures, value (value adding and value capture) and knowledge flows, institutional contexts as well as territorial arrangements of the chains.

Besides these academic and often very theoretical discussions, the practical importance of the approaches cannot be underestimated. The growing body of policy papers, handbooks and manuals, which see the value chain approaches as developmental concepts to be used to build up or optimize the value chains in various fields, confirm this. This also includes textbooks for future supply chain managers (e.g. Hertel et al., 2011) or guidebooks for the inclusion of farmers of the Global South into the value chains of agribusinesses (e.g. GIZ, 2012) as well as manuals for regional sourcing or marketing as part of endogenous regional development or environmental initiatives (e.g. Wannemacher \& Kuhnert, 2009). In this body of literature elements of the analytical tools are used as models to configure supply chains in a way that they fulfil the respective aims of the authors. These aims can range from fostering value capture in a region or saving carbon dioxide. Berndt and Boeckler (2011: 1068) name it "another species of 'economists in the wild' which has taken these efforts as a starting point to organize chain-like production whether referred to as value, commodity or supply chains transnationally and efficiently: the practitioners of supply-chain management $[\ldots]$ ".

These relationships and contradictions between value chain theory and value or supply chain practice were in the focus of the annual conference of the specialty group on rural geography of the German Association for Geography (Arbeitskreis Ländlicher Raum in der Deutschen Gesellschaft für Geographie) in Marburg in 2012. This section in the journal Economia agro-alimentare includes four out of the fourteen papers that were discussed on the conference.

The first article "The rise of supermarkets and challenges for small farmers in South African food value chains' by Peter Dannenberg analyses the impact of supermarkets on food value chains and especially the role of small 
farms in South Africa. To do so, Dannenberg links supply chain literature on smallholder inclusion with the GVC approach. The second article "Fair trade in Germany left the niche market. Power shifts observed in global fair trade value chains" by Jutta Kister uses the three case studies of coffee, chocolate and bananas to show how the fair trade relations between Germany and the Global South have changed since its start in the 1960s. She argues that a growing consumer orientation and the increasing importance of processed food have resulted in a shift of value-adding and decision-making processes. The shift has taken place from the Global South towards the Global North. In their article "The use of mobile phones by Kenyan export-orientated smallscale farmers - insights from fruit and vegetable farming in the Mt. Kenya region", Peter Dannenberg and Tobias Lakes show how the use of mobile phones can improve a farmer's business (and options) in areas such as payment, production, marketing, and knowledge transfer. These effects can result in a higher competitiveness and improve their prospects to get included into international value chains. In the last article Luisa Vogt looks at "The economic side of agrotourism - business performance and competitive factors". She analyses agrotourism in South Westphalia (GER). Her paper aims at measuring a company's competitiveness and at explaining its performance through factors like farm characteristics, resources and business strategies.

\section{Literature}

Berndt, C. \& Boeckler, C. (2011). Performative regional (dis)integration: transnational markets, mobiel commodities, and bordered North - South differences. Environment and Planning A 43, 1057-1078. doi: 10.1068/a4381.

Challies, E.R.T. \& Murray, W.E. (2011). The Interaction of Global Value Chains and Rural Livelihoods: The case of smallholder raspberry growers in Chile. Journal of Agrarian Change, 11(1), 29-59. doi: 10.1111/j.1471-0366.2010.00282.x.

Cook, I. (2006). Geographies of food: following. Progress in Human Geography, 30, 655-66. doi: 10.1177/0309132506070183.

Cook, I. \& Crang, P. (1996). The World on a Plate: Culinary Culture, Displacement and Geographical Knowledges. Journal of Material Culture, 1, 131-153. doi: $10.1177 / 135918359600100201$.

Dannenberg, P. (2011). Wege aus der Ausgrenzung - Informeller Umgang mit dem Standard GlobalGaP im kenianischen Gartenbau. Geographische Zeitschrift, 99(4), $237-55$.

Fine, B. \& Leopold, E. (1993). The World of consumption. London: Routledge.

Franz, M. \& Hassler, M. (2010). The value of commodity biographies: integrating tribal farmers in India into a global organic agro-food network. Area, 42(1), 2534. doi: 10.1111/j.1475-4762.2009.00893.x.

Friedland, W.H. (2005). Commodity systems: forward to comparative analysis. In N. Fold \& B. Pritchard (Eds.), Cross-continental Food Chains. London: Routledge, 25-38. 
Gereffi, G. \& Korzeniewicz, M. (1994). Commodity chains and global capitalism. Westport, CT: Praeger.

Gereffi, G., Humphrey, J. \& Sturgeon, T. (2005). The governance of global value chains. Review of International Political Economy, 12(1), 78-104. doi: 10.1080/ 09692290500049805.

GIZ - Deutsche GesellschaftfürInternationaleZusammenarbeit GmbH (2012). Growing Business with Smallholders - a Guide to Inclusive Agribusiness. Bonn, Eschborn.

Henderson, J., Dicken, P., Hess, M., Coe, N. \& Yeung H.W.-C. (2002). Global production networks and the analysis of economic development. Review of International Political Economy, 9(3), 436-464. doi: 10.1080/09692290210150842.

Hertel, J., Zentes, J. \& Schramm-Klein, H. (2011). Supply-Chain-Management und Warenwirtschaftssysteme im Handel. Berlin, Heidelberg: Springer.

Hopkins, T.K. \& Wallerstein, I. (1986). Commodity chains in the world-economy prior to 1800. Review, 10(1), 157-170.

Lenz, B. (1997). Das Filière-Konzept als Analyseinstrument der organisatorischen und räumlichen Anordnung von Produktions- und Distributionsprozessen. Geographische Zeitschrift, 85(1), 20-33.

Neilson, J. \& Pritchard, B. (2009). Value Chain Struggles: Institutions and Governance in the Plantation Districts of South India. West Sussex: Blackwell.

Oro, K. \& Pritchard, B. (2011). The evolution of global value chains: The displacement of captive upstream investment in the Australia-Japan beef trade. Journal of Economic Geography, 11(4), 709-729. doi:10.1093/jeg/lbq008.

Porter, M. (1985). Competitive Advantage: Creating and Sustaining Superior Performance. London: Macmillan.

Wannemacher, D. \& Kuhnert, H. (2009). Ausbau regionaler Wertschöpfungsketten zur Steigerung des Absatzes von ökologisch erzeugtem Gemüse im Lebensmitteleinzel- und Naturkosthandel. http://orgprints.org/18089/1/18089-06OE085-bioland-vollertsen-2009-regionaleWertschoepfungsketten.pdf [11.10.2013]. 